\title{
Analysis of temperament development during the fattening period in the semi-feral bovine calves of the Alberes Massif
}

\author{
Marta FINA $^{\mathrm{a}}$, Joaquim CASELlAs ${ }^{\mathrm{a}}$, Xavier MANTECA $^{\mathrm{b}}$, \\ Jesús PIEDRAFITA ${ }^{\text {a* }}$
}

\author{
${ }^{a}$ Grup de Recerca en Remugants, Departament de Ciència Animal i dels Aliments, \\ Universitat Autònoma de Barcelona, 08193 Bellaterra, Barcelona, Spain \\ ${ }^{\mathrm{b}}$ Departament de Biologia Cel.lular, Fisiologia i Immunologia, Universitat Autònoma de Barcelona, \\ 08193 Bellaterra, Barcelona, Spain
}

(Received 20 January 2005 - Accepted 15 May 2006)

\begin{abstract}
The aim of this study was to evaluate the progression of temperament in Alberes male calves during the fattening period. The Alberes breed is a semi-feral beef cattle breed of Catalonia (Spain) that lives endemically in the eastern extreme of the Pyrenees, a mountainous area. These animals were adapted to extensive management systems and their contact with humans was minimal until weaning. After weaning, eighty-four entire males from two consecutive years were reared in feedlot pens during the fattening period, weighed and graded for a temperament score once monthly. Behavioral records were analyzed under a repeated measures model, testing the influence of several systematic sources of variation. Three systematic effects reached statistical significance $(P<0.05)$ : weight of the calf at the beginning of the fattening period, initial temperament score, and restraint session within the initial temperament score. Calves with moderate and high temperament scores at the beginning of the fattening period tended to moderate their temperament $(P<0.05)$, whereas calm calves did not show a significant trend. Our results suggest that behavioral agitation is decreasing over time in excitable calves, obtaining an acceptable level of tameness for these animals. The effect of the initial weight could be related with calf age, suggesting that older calves were less adaptable to intensive fattening systems.
\end{abstract}

beef cattle / calf behavior / cattle handling / human-animal relation / calf welfare

Résumé - Analyse du développement du tempérament pendant la période d'engraissement chez le jeune bovin semi-sauvage du massif des Albères. Le but de cette étude était d'évaluer l'évolution du tempérament des jeunes mâles de la race Albères pendant leur période d'engraissement. La race Albères est une race bovine semi-sauvage native de la Catalogne (Espagne). C'est une population endémique localisée à l'extrémité est des Pyrénées. Ces animaux ont été adaptés au système d'élevage extensif et leur contact avec les humains a été minimal jusqu'au sevrage. Après

\footnotetext{
*Corresponding author: jesus.piedrafita@uab.es
} 
le sevrage, 84 mâles entiers, au cours de deux années consécutives, ont été élevés en feedlot pendant la période d'engraissement. Leur poids et leur tempérament (note de 1 à 5, du plus calme au plus nerveux) ont été évalués une fois par mois. Les comportements observés ont été analysés avec un modèle de mesures répétées, en examinant l'influence de plusieurs sources de variation. Ils ont été influencés $(P<0,05)$ au cours de l'étude par trois facteurs : le poids du veau au début de la période d'engraissement, la note initiale de tempérament, et la note de tempérament pendant la session de contrainte (feedlot). Les animaux avec des notes de tempérament moyennes ou élevées au début de la période d'engraissement ont eu tendance à modérer leur tempérament $(P<0,05)$; avec les animaux calmes aucune tendance significative n'a été montrée. Nos résultats suggèrent que l'agitation des animaux les plus nerveux diminue avec le temps, ce qui permet d'obtenir un niveau de domestication acceptable. L'effet du poids initial pourrait être lié à l'âge du veau, suggérant ainsi que plus un veau est âgé moins il est adaptable aux systèmes intensifs d'engraissement.

bovin / comportement / manipulation du bétail / relation humain-animal / bien-être

\section{INTRODUCTION}

Temperament in cattle reared under extensive management systems can involve difficulties for handling. This trait, defined as the characteristic way an individual behaves, is related to human presence or human handling [11] and is important for the welfare of the animal and the safety of the stockperson which can be at risk during handling [13]. Indeed, in ruminant livestock, routine management procedures can involve negative emotions, such as fear, which affect animal welfare negatively [3]. The frequency and the magnitude of fear responses by farm animals in the presence of humans are substantially different in modern intensive animal production systems than in extensive ones [16]. Grouped cattle tend to be less behaviorally agitated during routine handling $[10,12]$. Some beef producers consider temperament to be an important trait when selecting cattle for purchase [9], and no one wants to raise wild cattle. In commercial conditions, fear of people can lead to decreased welfare and productivity of domestic livestock $[1,9,18,25]$. The animals have adapted their behavior during domestication and we need to understand why they behave the way they do. Apart from management, other important factors like genetic background, sex and previous experiences influence the behavioral response of animals [17]. In this sense, Hutson [20] described that cattle and sheep can remember an aversive experience for many months. In addition, temperament has been related to production traits such as daily weight gain [27] or meat quality [16]. Drugociu et al. [8] reported that dairy cows with calm temperaments had increased milk production and Bramblett et al. [2] demonstrated that stressful treatment during growth can have adverse effects on meat quality in lambs. In commercial conditions, fear of people can decrease calf welfare and productivity and put animals under stress, which reduces muscle glycogen level in vivo [28] and increases ultimate $\mathrm{pH}$ of muscles and the presence of dark-cutting meat [16] and makes the useful life shorter [15].

The Alberes calves from the Natural Park of the Alberes Massif, situated in the eastern part of the Pyrenees, belong to a semi-feral bovine population, which is adapted to extensive management systems and the geo-climatic conditions of this region. Adult individuals live free all year around with minimal human contact and calves are reared by their dams until weaning, remaining in the herd until an age of 6 to 9 months, when the intensive fattening period starts. Because of these management characteristics, rather different from the common husbandry practices, these animals are an appropriate material to carry out a study on the evolution of calf temperament. 
This research will allow us to study the temperament of beef calves coming from extensive management systems when they enter the feedlot. Although several studies have been carried out, the progressive reduction of the temperament score in beef cattle implies a great controversy because significant $[7,22]$ and non-significant $[5,14]$ trends have been reported. Moreover, highly excitable animals can suffer from a reduced welfare. In ruminant livestock, genetic selection based on reduced fearfulness to increase their adaptive abilities could be as significant to their welfare as the systems in which they are managed [3]. Therefore, the analysis of temperament was the objective of this paper where we describe the behavior of Alberes calves and their development on the basis of the initial temperament score. The effect of the year of birth, weaning weight and average daily growth were also tested.

\section{MATERIALS AND METHODS}

\subsection{The Alberes cattle}

The Alberes population is a native bovine breed of Catalonia distributed between the Alt Empordà region (Spain) and the Vallespir region (France), in the eastern extreme of the Pyrenees. This population has been grouped within the Cantabrian trunk although some other breeds may also have influenced the population along its history [6]. Individuals ascend to pastures in the mountains during the spring and summer and browse shrubs and branches of Mediterranean wood in cold seasons. In this adverse period, the animals live grouped in three herds close to three old farmhouses where they receive supplementary feed. When the caretakers spread this additional feed, minimal or absent human contacts took place. Once a year, the herds are restrained within small fences to worm animals and wean male calves.

\subsection{Data Source}

Behavioral observations were registered on 84 entire Alberes males coming from the fattening batches of two consecutive years (47 in the first year, 37 in the second), while calves were restrained to weigh them along the fattening period. The age of calves at the beginning of the study fluctuated between 6 and 9 months although we did not know the precise age of each animal because the birth date is not recorded in the management system of the Alberes breed. The individuals were housed in barns in reduced groups (average of 10 young bulls) where they were fed ad libitum with a specific diet based on standard concentrate meal (crude protein around $14 \%$ or slightly upper; energy $1 \mathrm{UFC} \cdot \mathrm{kg}^{-1}$; and balanced for $\mathrm{Ca}$ and P) and straw for the maintenance of ruminant ability. No special management or treatment was given to the animals. At the end of the fattening period, calves were slaughtered.

\subsection{Temperament ratings and restraint sessions}

The animals walked around the working chute and were weighed while an observer, always the same person, graded the animals for a temperament score according to a five point-scale (Tab. I) [14]. The assignment of the temperament note was done when the animal was restrained on the top of the scale while the observer recorded the weight. In this study, we had four restraint sessions separated by an average of 28 days. During all handling and restraint sessions, care was taken to handle the animals gently.

\subsection{Statistical analysis}

The evolution of the Alberes calf behavior on successive weightings was assessed 
Table I. Temperament scores during the restraint sessions while the animals were weighed [14].

\begin{tabular}{lc}
\hline Score & Temperament signs \\
\hline 1 & Calm, no movement \\
2 & Slightly restless \\
3 & Squirmy \\
4 & Continuous, very vigorous movements \\
5 & Rearing, twisting of the body and struggling violently \\
\hline
\end{tabular}

${ }^{1}$ Squirmy is synonymous of to become tangled, to get twisted into the squeeze chute and trying to slip away from it.

through a repeated measures analysis. The preliminarily model assumed was the following:

$$
\begin{aligned}
\mathrm{y}_{\text {mnopqr }}=\mu+\mathrm{A}_{\mathrm{m}}+\mathrm{B}_{\mathrm{n}}+\mathrm{D}_{\mathrm{o}} & +\mathrm{W}_{\mathrm{p}}+\mathrm{T}_{\mathrm{q}}+\mathrm{S}_{\mathrm{r}}\left(\mathrm{T}_{\mathrm{q}}\right) \\
& +\mathrm{S}_{\mathrm{r}}^{2}\left(\mathrm{~T}_{\mathrm{q}}\right)+\mathrm{e}_{\mathrm{mnopqr}}
\end{aligned}
$$

where $y_{\text {mnopqr }}$ was the behavior record, $\mu$ was the overall mean and $\mathrm{e}_{\text {mnopqr }}$ the residual random effect. The factors considered were the following: (1) random animal effect $\left(\mathrm{A}_{\mathrm{m}}\right)$; (2) year effect with two levels: 2002 and $2003\left(B_{n}\right) ;(3)$ daily growth obtained by the weight difference between the first and last weighting divided by the days elapsed $\left(D_{0}\right)$; (4) first or initial score of temperament with 2 levels resulting from the grouping of scores 1 and 2 as Calm animals and scores 3, 4 and 5 as Excitable animals in order to avoid groups with an excessively small size $\left(\mathrm{T}_{\mathrm{q}}\right)$; (5) linear and quadratic effect of a restraint session as a covariate within the two levels of $T_{q}$ $\left(\mathrm{S}_{\mathrm{r}}\left(\mathrm{T}_{\mathrm{q}}\right)\right.$ and $\mathrm{S}_{\mathrm{r}}^{2}\left(\mathrm{~T}_{\mathrm{q}}\right)$ respectively); (6) initial weight in the first restraint session taken as a covariate $\left(\mathrm{W}_{\mathrm{p}}\right)$.

Before rejecting the non significant effects, each of them was tested with the group of initially significant fixed effects to determine whether any became significant. After excluding the effects that did not reach the statistical significance, the operational final model was the following:

$$
\mathrm{y}_{\mathrm{mnopqr}}=\mu+\mathrm{W}_{\mathrm{p}}+\mathrm{T}_{\mathrm{q}}+\mathrm{S}_{\mathrm{r}}\left(\mathrm{T}_{\mathrm{q}}\right)+\mathrm{e}_{\mathrm{mnopqr}}
$$

The covariance structures tested were the compound symmetry type (CS), which is traditionally used and the first-order autoregressive type (AR-1) which reflects measurement occasions that are closer in time and are more highly correlated than those farther apart in time. The Akaike's Information Criterion (AIC) was used to decide which model was preferable according to the covariance structure used. In this case, the first-order autoregressive type had been chosen. Data were analyzed using the SAS MIXED procedure [24].

\section{RESULTS}

At the beginning of the fattening period, calves had an average weight of $279.34 \mathrm{~kg}$ with a standard deviation of $61.98 \mathrm{~kg}$. The calf behavior was significantly influenced by initial calf weight, initial temperament score, and restraint session nested within initial temperament score $(P<0.05)$. The estimates of these significant effects are described in Table II. The average temperament values for calm and excitable animals are shown in Figure 1. The behavior had a different evolution depending on the initial temperament score (Fig. 1). On this basis, the animals with an agitated behavior, the excitable animals, reduced their temperament score with a 0.25 point scale every time they were weighed, whereas the animals from the first group, 


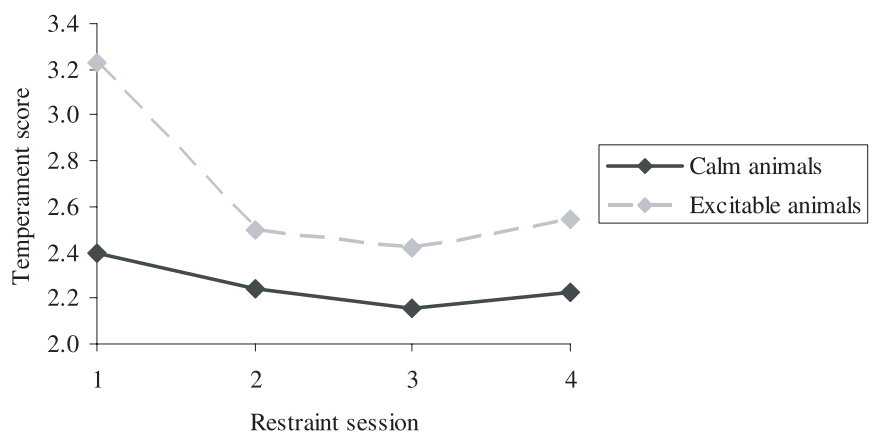

Figure 1. Means of temperament score along the sessions according to the two groups of initial temperament (Calm animals and Excitable animals).

Table II. Estimates and standard errors of the effects that describe the temperament evolution.

\begin{tabular}{lcc}
\hline Tested parameter & Estimate & Standard Error \\
\hline Intercept & 3.038 & 0.463 \\
Initial weight & 0.002 & 0.001 \\
Initial temperament score & & \\
$\quad$ Calm animals & -1.111 & 0.380 \\
$\quad$ Excitable animals & 0 & \\
Restraint session within initial temperament score & & \\
$\quad$ Calm animals & -0.129 & 0.075 \\
$\quad$ Excitable animals & -0.256 & 0.118 \\
\hline
\end{tabular}

the calm animals, did not show any significant tendency. Likewise, the behavior score increased with the initial weight of the calf.

\section{DISCUSSION}

The measure of the relative docility, wildness or aggression of an animal toward unfamiliar situations, human handlers or management interventions is a way to describe the temperament and reflects how easily the animals respond to handling, treatment and routine management. Our data showed a trend in the behavioral reactions of excitable beef calves evaluated through a temperament score test (Fig. 1). That trend could be related to regular human contact, the first and following exposures to the test situation or just the calf age. The lack of a control group did not allow us to determine the effect of human contact separately, although it might be considered as a very important factor because the beef caretakers carried out the same handling practices in each restraint session. Lanier et al. [21] observed that cattle that become agitated during handling in an auction ring are more sensitive to sudden touches and sudden or intermittent movements and sounds. They reported that the differences in animal handling between auctions may have had an effect on cattle temperament. Therefore, that reactivity to intermittent stimuli may be useful for predicting which cattle would be more likely to become agitated when exposed to a new place [21].

Furthermore, the results shown in Table II allow us to conclude that the 
behavior of Alberes calves with regular management improved in the animals that had high initial temperament scores. This fact was partially in agreement with Le Neindre [22], who reported that regular handling decreases subsequent reactivity to humans in cattle, or with Crookshank et al. [7] who found that in cattle, agitation and cortisol levels decreased with subsequent experiences in the handling facility because cattle became habituated. However, Grandin [14] and Burrow [5], observed that intensive handling in animals did not improve their temperament on the short or long-term. Therefore, to increase the tameness of calves and the farmers' safety during animal handling, calves need periods with human contact to provide an easier animal management [22]. In our analysis, daily gain did not influence behavior although, on the contrary, some authors like Voisinet et al. [27] and Tulloh [26], point out that more excitable cattle with higher temperament scores had lower live weights and (or) weight gains. This lack of significance could be due to the highly dispersed values of daily gain in the beginning of the fattening period because the animals were taken from the mountain at different ages and grouped in feedlots without a size criterion.

The evolution of behavior in Alberes male calves showed differences depending upon the initial weight. This was also correlated with the calves' age and therefore, the time that they stayed on the mountain with their mothers without or with minimal human contacts. If the animals were older, it was more difficult for them to become accustomed to the new environment than the younger ones, as was suggested by Markowitz et al. [23] in lambs.

The social environment in which the calf lives after weaning, without the care of the mother and with daily human contact, influences calf behavior during the fattening period. Even then, the initial response of a farm animal to humans could be explained by its emotional reactivity and, the subsequent experience with persons induces the development of a specific response to humans [19]. Therefore, both the attitude and behavior of stockpersons towards farm animals are important determinants of the behavioral responses of these animals to humans [19]. Despite this fact, Boivin et al. [4] found a significant effect of the management system during the first months of the animal's life, when animals reared indoors were more docile than the others reared in other places.

In conclusion, our results suggest that the temperament of the semi-feral Alberes calves can be improved during the fattening period although the influence of the handling procedures could not have been specifically analyzed. Our results will contribute to the management procedures of the Alberes breed and they are an endeavour to go deeply in the knowledge of the calf temperament under intensive feeding systems.

\section{ACKNOWLEDGEMENTS}

The Servei de Producció Ramadera of the Departament d'Agricultura, Ramaderia i Pesca (Generalitat de Catalunya) gave financial support to this study. We thank A. Carola, owner of the animals, and the caretakers of the Alberes population, for his active and friendly collaboration.

\section{REFERENCES}

[1] Barnett J.L., Hemsworth P.H., Newman E.A., Fear of humans and its relationships with productivity in laying hens at commercial farms, Brit. Poultry Sci. 33 (1992) 699710.

[2] Bramblett V.D., Judge M.D., Vail G.E., Stress during growth: II. Effects on palatability and cooking characteristics of lamb meat, J. Anim. Sci. 22 (1963) 1064-1067.

[3] Boissy A., Fisher A.D., Bouix J., Hinch G.N., Le Neindre P., Genetics of fear in ruminant livestock, Livest. Prod. Sci. 93 (2005) 23-32. 
[4] Boivin X., Le Neindre P., Chupin J.M., Garel J.P., Trillat G., Influence of breed and early management on ease of handling and openfield behaviour of cattle, Appl. Anim. Behav. Sci. 32 (1992) 313-323.

[5] Burrow H.M., Measurements of temperament and their relationships with performance traits of beef cattle, Anim. Breed. Abstr. 65 (1997) 477-495.

[6] Casellas J., Jiménez N., Fina M., Tarrés J., Sánchez A., Piedrafita J., Genetic diversity measures of the bovine Alberes breed using microsatellites: variability among herds and types of coat colour, J. Anim. Breed. Genet. 121 (2004) 101-110.

[7] Crookshank H., Elissalde M., White R., Clanton D., Smolley H., Effect of handling and transportation of calves upon blood serum composition, J. Anim. Sci. 48 (1979) 430.

[8] Drugociu G., Runceanu L., Nicorici R., Hritcu V., Pascal S., Nervous typology of cows as a determining factor of sexual and productive behaviour, Anim. Breed. 45 (1977) 1262 (Abstr.).

[9] Elder J.K., Kearnan J.F., Waters K.S., Dunwell G.H., Emmerson F.R., Knott S.G., Morris R.S., A survey concerning cattle tick control in Queensland. 4. Use of resistant cattle and pasture spelling, Aust. Vet. J. 56 (1980) 219-231.

[10] Ewbank R., The behavior of animals in restraint, in: Fox M.W. (Ed.), Abnormal behavior in animals, W. B. Saunders Co., Philadelphia, PA, 1968, pp. 159-178.

[11] Gauly M., Mathiak H., Hoffmann K., Krauss M., Erhardt G., Estimating genetic variability in temperamental traits in German Angus and Simmental cattle, Appl. Anim. Behav. Sci. 74 (2001) 109-119.

[12] Grandin T., Animal handling, Vet. Clin. 3 (1987) 323-338.

[13] Grandin T., Behavioral principles of livestock handling, J. Anim. Sci. 5 (1989) 1-11.

[14] Grandin T., Behavioral agitation during handling of cattle is persistent over time, Appl. Anim. Behav. Sci. 36 (1993) 1-9.

[15] Grandin T., Animal handling troubleshooting guide, Meat Poultry March (2000) 6469.
[16] Gregory N.G., Grandin T., Animal Welfare and Meat Science, CAB International, Wallingford, UK, 1998.

[17] Gonyou H.W., Behavioral principles of animal handling and transport, in: Grandin T. (Ed.), Livestock Handling and Transport, 2nd ed., CAB International, Wallingford, 2000.

[18] Hemsworth P.H., Brand A., Willems P., The behavioural response of sows to the presence of humans beings and its relation to productivity, Livest. Prod. Sci. 8 (1981) 67-74.

[19] Hemsworth P.H., Price E.O., Borgwardt R., Behavioural responses of domestic pigs and cattle to humans and novel stimuli, Appl. Anim. Behav. Sci. 50 (1996) 43-56.

[20] Hutson G.D., The influence of barley food rewards on sheep involvement through a handling system, Appl. Anim. Behav. Sci. 14 (1985) 263-273.

[21] Lanier J.L., Grandin T., Green R.D., Avery D., McGee K., The relationship between reaction to sudden, intermittent movements and sounds and temperament, J. Amin. Sci. 78 (2000) 1467-1474.

[22] Le Neindre P., Boivin X., Boissy A., Handling of extensively kept animals, Appl. Anim. Behav. Sci. 49 (1996) 73-81.

[23] Markowitz T.M., Dally M.R., Gursky K., Price E.O., Early handling increases lamb affinity for humans, Anim. Behav. 55 (1998) 573-587.

[24] SAS $^{\circledR}$ User's Guide, Statistics, version 8, SAS Institute Inc., Cary, NC, 2001.

[25] Seabrook M.F., The psychological interaction between the stockman and his animals and its influence on performance of pigs and dairy cows, Vet. Rec. 115 (1984) 84-87.

[26] Tulloh N.M., Behaviour in cattle yards. II. A study of temperament, Anim. Behav. 9 (1961) 25-30.

[27] Voisinet B.D., Grandin T., Tatum J.D. O'Connor S.F., Struthers J.J., Feedlot cattle with calm temperaments have higher daily gains than cattle with excitable temperaments, J. Anim. Sci. 75 (1997) 892-896.

[28] Warris P.D., The handling of cattle preslaughter and its effects on carcass and meat quality, Appl. Anim. Behav. Sci. 28 (1990) 171-186. 